\title{
Relationship Between Quality of Home Environment, Locus of Control and Achievement Motivation Among High Achiever Urban Female Adolescents
}

\author{
Shelly Bansal, S.K. Thind and S. Jaswal \\ Department of Human Development and Sociology, Punjab Agricultural University, Ludhiana \\ 141 004, Punjab, India
}

KEYWORDS Quality of Home Environment. Locus of Control. Achievement Motivation. High Achiever. Adolescents

\begin{abstract}
The present study is based on one hundred eleventh grade students drawn from ten senior secondary schools of Ludhiana City. All the selected respondents had scored 80 per cent or above aggregate marks in their tenth standard examination and were thus labeled as 'high achievers'. Rotter's Locus of Control, Bhargava's Achievement Motivation Scale and Misra's Home Environment Inventory Scale were used to assess the locus of control, achievement motivation and quality of home environment, respectively. Results showed that good quality of home environment had significant positive correlation with 'high' level $(\mathrm{P}<0.001)$ of achievement motivation among high achievers. It was found that as the quality of home environment gets deteriorated, the level of achievement motivation also gets deteriorated. 'Internal' locus of control had significant positive correlation with quality of home environment. 'External' locus of control was non-significantly related with achievement levels and quality of home-environment. Significantly greater proportion of high achievers with 'average' level of achievement motivation showed 'internal' locus of control. Whereas distribution of high achievers with high and low levels of achievement motivation showed no significant difference for the internal and external locus of control.
\end{abstract}

\section{INTRODUCTION}

In our society academic achievement is considered as a key criteria to judge one's total potentialities and capabilities. Therefore, it is becoming more and more pressing for the individuals to have good academic achievement. Academic achievement has become an index of child's future particularly so in highly competitive world. Research studies have proved that a supportive nurturing environment in home and school could enhance child's academic achievement.

Family being the first and major agency of socialization plays a pivotal role in styling child's life. It has been shown that most of children who are successful and well adjusted come from families where wholesome relationships exist between children and their parents.

Achievement and motivation are important determinants of aspiration and effort when an individual expects that his performance will be evaluated in relation to some standard of excellence. Therefore, achievement motivation can be defined as a concern for excellence in performance as reflected in competition with the standards set by others or over unique accomplishment or long time involvement (McCleland, 1953). It is one of the basic ingredients necessary for one's success in life.
Different factors of personality also play an important role in academic achievement. One of the stable dimensions of personality is locus of control. People have different perceptions about the factors responsible for their achievements. These perceptions are referred to as perceived locus of control. Some people tend to see the things that happen to them as primarily under their own control. Such people are referred to as internals. In other words, their perceived locus of control is internal or within themselves. The person with an internal locus of control attributes success to his or her own efforts and abilities. He will be more motivated, more likely to learn and is more likely to have good study habits and positive academic attitude (Scott et al., 1991).

In contrast, other persons may tend to see their achievements as largely outside their own control. They believe that events are controlled by many other factors such as luck, chance or help of the teacher, friends or relatives. Such people have an external locus of control and referred as externals. A person with an external locus of control attributes his or her success to luck or fate and may make fewer efforts needed to learn. People with external locus of control are also more likely to experience anxiety since they believe that they are not in control of their lives (Ferguson, 1987). 
The purpose of the present study was to ascertain the relationship among the quality of home environment, achievement motivation and locus of control among 'high achiever' urban female adolescents

\section{MATERIAL AND METHODS}

The sample for the present study consisted of adolescent girls in the age group of 15 to 18 years from Ludhiana City who were enrolled in class $10+1$. The sample for the present study consisted of 100 respondents on the basis of marks obtained in their tenth standard examination. The students scoring 80 per cent or above aggregate marks were considered as high achievers. In each school the first ten students from the category of high achievers were selected as a sample of the study. Rotter's Locus of Control (2002), Bhargava Achievement Motivation Scale (1994) and Home Environment Inventory by Misra (1989) were used to assess the locus of control, achievement motivation and quality of home environment, respectively.

\section{RESULTS AND DISCUSSION}

Quality of Home Environment, Locus of Control and Achievement Motivation: Ten dimensions of quality of home environment have been explored in relation to achievement motivation and locus of control among 'high achievers'.

Protectiveness and Permissiveness: 'Protectiveness' the dimension of quality of home environment implies prevention of independent behaviour and prolonged action of infantile care. 'Permissiveness' includes 'Provision' of opportunities to child to express his/her views freely and act according to his/her desires with no interference from parents.
Table 1 shows that protection and permissiveness were significantly and positively correlated with all the levels of achievement motivation among 'high achievers'. Protectiveness and permissiveness may be enhancing achievement motivation among high achievers but have been found to be negatively associated with interpersonal skills (Scott et al., 1991).

The 'Permissiveness' dimension of quality of home environment showed non-significant correlation with 'Internal' as well as 'External' locus of control. It could thus be inferred that protectiveness is detrimental for 'internal' locus of control whereas external locus of control is neither regulated by 'protectiveness' or 'permissiveness' dimensions of quality of home environment.

Control and Punishment: The dimension 'Control' of quality of home environment is defined here as an autocratic environment in which restrictions are imposed on children by parents in order to discipline them. 'Punishment' includes 'physical' as well as 'affective' punishment to avoid the occurrence of undesirable behaviour.

Control and Punishment variables of home environment were significantly correlated (positively) with high and average level of achievement motivation, whereas the correlation was significantly negatively correlated with low levels of achievement motivation among high achievers (Table 1). These observations thus point out that control and punishment play a positive role in enhancing the achievement motivation. The negative relationship of these dimensions with low level of achievement motivation might be indicative of their magnitude i.e., these measures might be ineffective in enhancing achievement motivation if their application crossed optimum limits

It has also been reported by Estrada et al.

Table 1: Relationship between quality of home environment and achievement motivation among high achievers.

\begin{tabular}{|c|c|c|c|c|c|c|c|c|c|c|c|}
\hline \multirow{2}{*}{$\begin{array}{l}\text { Achievement } \\
\text { motivation } \\
\text { levels }\end{array}$} & \multicolumn{11}{|c|}{$r$-correlation $c$} \\
\hline & Control & $\begin{array}{l}\text { Protec- } \\
\text { tiveness }\end{array}$ & $\begin{array}{c}\text { Punish- } \\
\text { ment }\end{array}$ & $\begin{array}{l}\text { Confor- } \\
\text { mity }\end{array}$ & $\begin{array}{c}\text { Social } \\
\text { isolation }\end{array}$ & Reward & $\begin{array}{l}\text { Depri- } \\
\text { vation of } \\
\text { privilege }\end{array}$ & $\begin{array}{c}\text { Nurtu- } \\
\text { rance }\end{array}$ & Rejection & $\begin{array}{c}\text { Permissi- } \\
\text { veness }\end{array}$ & Total \\
\hline High & $0.27 * *$ & $0.42 * * *$ & $0.20 * *$ & $0.37 * * *$ & 0.08 & $0.39 * * *$ & $* 0.16^{*}$ & 0.005 & -0.077 & $0.16 * 0$ & $.414 * * *$ \\
\hline Average & $0.28 * *$ & $0.13^{*}$ & $0.13^{*}$ & -0.04 & 0.016 & $0.17 *$ & $-0.14 *$ & $-0.26^{* *} *$ & $0.40^{* * * *}$ & $*-0.13^{*}$ & $0.155^{*}$ \\
\hline Low & $-0.12 *$ & $0.11 *$ & $-0.24 * *$ & $-0.17 *$ & $-0.29 * *$ & $-0.33 * * *$ & $*-0.02$ & $0.15^{*}$ & 0.09 & $0.38 * * *$ & $-0.13 *$ \\
\hline
\end{tabular}

$*$ = Significant at $\mathrm{P}<0.05 * * *=$ Significant at $\mathrm{P}<0.01 \quad * * *=$ Significant at $\mathrm{P}<0.001$ 
(1987) that a positive affective relationship between parents and children increases the likelihood that the child will initiate and persist in challenging and intellectual tasks. Positive and affective relationship is likely to get hampered when control and punishment exist beyond optimum limits. The study by Ferguson (1987) showed that Parent's behaviour is essential component of home environment and is related to cognitive development through the amount of interaction, provision of support in problem solving activities and allowing children to explore. Such studies thus imply that controlling and punitive home environment is essentially detrimental for cognitive development and thus academic achievement. The present results imply that control and punishment would be possibilly valued for high and average level of achievement motivation where as beyond optimum limits would induce low level of achievement motivation among high achievers.

Conformity and Reward: 'Conformity' refers to the parent's directions, commands or orders with which child is expected to comply by actions or demands to work according to parents' desires and expectations. 'Reward' includes materialistic as well as symbolic reward to strengthen or increase the probability of desired behaviour.

The results of the present study showed that conformity and reward are positively correlated with high level of achievement motivation and negatively correlated with low level of achievement motivation (Table 1). The negative correlation of conformity and reward with low level of achievement motivation could be due to excessive magnitude where these tend to lose their positive value in promoting achievement motivation. The study by Dornbusch and Ritter (1992) showed that parental encouragement and rewards for grades are positively associated with improvements in academic performance.

Deprivation of Privileges: It implies controlling behaviour of children by depriving them of their rights to seek love, respect and child care from parents. The present study showed that parental strategy for motivating children for achievement by depriving them from privileges was positively and significantly correlated with high level of achievement motivation (Table 1). On the other hand it was found negatively and significantly correlated with low level of achievement motivation. In other words it worked well for $68 \%$ of high achievers and did not work well for the remaining 34\%. It has been found that socializer's use of power-assertive techniques of discipline (Physical punishment, deprivation of privileges or threats of either of these) have been found to be either unrelated or negatively related (BarTal et al., 1980) to children's prosocial development. It should be noted, however, that there is a difference between the occasional use of power assertive techniques in the context of positive parent-child relationship, and the use of punishment as the preferred, predominant mode of discipline. When power-assertive techniques are used in a measured and rational manner by parents who generally are warm and supportive, set high standards, and usually use non-power assertive disciplinary techniques such as reasoning, children tend to be socially positive (Baumrind, 1971) and could have high achievement motivation. In contrast, it appears that the frequent use of power-assertive techniques may result into lowering the achievement motivation level.

Social Isolation: It means use of isolation from beloved person except family members for negative sanctions. The present results showed that social isolation was not related with high and average level of achievement motivation. However, it was negatively and significantly related with low level of achievement motivation (Table 1).

These results appear to be indicating that social isolation if used rationally may not affect the high and average level of achievement motivation. In case it happens to be the preferred mode of disciplining the child, it may lower his/ her achievement motivation.

Nurturance: 'Nurturance' here means existence of excessive unconditional physical and emotional attachment of parents with the child. The results of the present study showed that 'Nurturance' that is 'excessive unconditional love' was negatively correlated with high and average achievement motivation. In other words lesser the 'excessive unconditional love', higher shall be the achievement motivation level. It was found to be unrelated with low level of achievement motivation (Table 1).

Rejection: It implies conditional love, recognizing that child has no right as a person, no right to express his feelings, no right to uniqueness and no right to become autonomous individual. 'Rejection' component of the home environment was found to be unrelated with high 
Table 2: Relationship between locus of control and quality of home environment among high achievers.

\begin{tabular}{|c|c|c|c|c|c|c|c|c|c|c|c|}
\hline \multirow[t]{2}{*}{$\begin{array}{l}\text { Locus of } \\
\text { control }\end{array}$} & \multicolumn{11}{|l|}{$r$-correlation } \\
\hline & Control & $\begin{array}{l}\text { Protec- } \\
\text { tiveness }\end{array}$ & $\begin{array}{l}\text { Punish- } \\
\text { ment }\end{array}$ & $\begin{array}{l}\text { Confor- } \\
\text { mity }\end{array}$ & $\begin{array}{c}\text { Social } \\
\text { isolation }\end{array}$ & Reward & $\begin{array}{c}\text { Depri- } \\
\text { vation of } \\
\text { privilege }\end{array}$ & $\begin{array}{c}\text { Nurtu- } \\
\text { rance }\end{array}$ & Rejection $I$ & $\begin{array}{c}\text { Permissi- } \\
\text { veness }\end{array}$ & Total \\
\hline Internal & 0.095 & $-0.161 *$ & $0.238 * *$ & $0.122 *$ & $* 0.155^{*}$ & $0.139 *$ & $0.172 *$ & 0.079 & $0.280 * *$ & $* 0.067$ & $0.273^{* *} *$ \\
\hline External & -0.069 & 0.0745 & $0.181 *$ & $-0.139 *$ & $-0.241^{*}$ & $0.120 *$ & $-0.171 *$ & $-0.302 * *$ & $0.454 * *$ & * -0.041 & -0.095 \\
\hline
\end{tabular}

$*$ = Significant at $\mathrm{P}<0.05 * *=$ Significant at $\mathrm{P}<0.01 * * *=$ Significant at $\mathrm{P}<0.001$

and low level of achievement motivation. Only the average level of achievement motivation was positively and significantly correlated with rejection (Table 1 ).

\section{Quality of Home Environment and Locus of Control}

1. Internal Locus of Control: Internal locus of control was found to be positively correlated with punishment, conformity, social isolation, reward, deprivation of privileges and rejection. It was negatively correlated with protectiveness. No correlation existed for control, nurturance and permissiveness.

2. External Locus of Control: It was negatively correlated with social isolation, deprivation of privilege, nurturance and rejection. It was positively correlated with punishment and reward. It showed no correlation with control, protectiveness, conformity and permissiveness dimensions of quality of home environment.

It was also observed that $60 \%$ of high achievers showed 'Internal' locus of control whereas only $40 \%$ of them were recorded for 'external' locus of control. It could be inferred from the above that punishment, conformity, social isolation, reward, deprivation of privileges and rejection enhance external locus of control among high achievers.

Achievement Motivation and Locus of Control: It was observed that 68 percent of the high achievers had high level of achievement motivation whereas average level of achievement motivation was recorded for 17 percent. Low level of achievement motivation was found for 15 percent of high achievers. From this information, it could be inferred that high achievement level does not guarantee the same level of achievement motivation. Among high achievers, these could be individuals (32\%) who would have achievement levels other than high achievement level. Comparison of proportions of female adolescents at high, average and low level of achievement motivation showed significant differences for internal locus of control (Table 3). Significantly greater proportion of high achievers with 'average' level of achievement motivation showed 'internal' locus of control. Whereas distribution of high achievers with high and low levels of achievement motivation showed no significant difference for the internal and external locus of control. No other comparison in this respect showed significant differences.

\section{CONCLUSION}

It could be concluded from the results of the present study that quality of home environment plays an important role in determining magnitude of achievement motivation and internal locus of control for high level of academic achievement.

Some of the dimensions of quality of home environment such as control, protectiveness, conformity, punishment, reward, social isolation,

Table 3: Statistical significance of difference in distribution of respondents with 'internal' and 'external' locus of control across three levels of achievement motivation among high achievers

\begin{tabular}{lccc}
\hline \multirow{2}{*}{ Locus of control } & \multicolumn{3}{c}{ Achievement motivation levels } \\
\cline { 2 - 4 } & High & Average & Low \\
\hline Internal $(\mathrm{n}=72)$ & $\mathrm{n}=53$ & $\mathrm{n}=10$ & $\mathrm{n}=9$ \\
& $(73.61 \%)$ & $(13.89 \%)$ & $(12.50 \%)$ \\
External $(\mathrm{n}=28)$ & $\mathrm{n}=20$ & $\mathrm{n}=2$ & $\mathrm{n}=6$ \\
& $(71.42 \%)$ & $(7.14 \%)$ & $(21.42 \%)$ \\
Z-value & $0.22^{\mathrm{NS}}$ & $9.74 * *$ & $-1.278^{\mathrm{NS}}$
\end{tabular}

$\mathrm{NS}=$ Non significant $\quad * *=$ Significant at $\mathrm{P}<0.001$ 
deprivation of privileges and rejection emerged as the most significant for inculcating high level of achievement motivation and internal locus of control for ensuring high level of academic achievement.

External locus of control for high level of academic achievement was not related to the quality of home environment whereas internal locus of control across high level of academic achievement was significantly determined by the quality of home environment.

The present results are supported by the earlier findings by Morrow and Wilson (1961) that, the parents of bright, high achievers in school engage more in sharing of activities, and were approving, trusting and affectionate with their children. They encouraged achievement but did not exert pressure.

Similarly, Paulson (1996) also indicated that parental involvement had a positive effect on adolescent achievement. The results also subscribe to the view that where parents of 'high achievers' provide good quality home environment, ensuring balance in all its quality dimensions, children get induced to higher achievement motivation levels and tend to inculcate 'internal' locus of control.

\section{REFERENCES}

BarTal, D., Nadler, A. and Blehman N.: The relationship between Israeli children's helping behaviour and their perception on parent's socialization practices. J. Soc. Psychol., 111: 159-167 (1980).

Baumrind, D., Current patterns of parental authority. Develop. Psychol. Monograms, 1: 1-103 (1971).

Bhargava, V.P.: Manual for Achievement Motivation Scale: National Psychological Corporation, Agra (1994).

Dornbusch, S. M. and Ritter, P. L.: Home school processes in diverse ethnic groups, social classes, and family structures. pp. 111-125. In: Home-school collaboration: Enhancing Students Academic and Social Competence. S. L. Christenson and J. C. Conoley (Eds.). Basic Books, New York (1992).

Estrada, P. Arsenio, W. E. Hess, R. D. and Holloway, S.: Affective quality of the mother-child relationship: Longitudinal consequences for children's school-relevant cognitive functioning. Develop. Psychol., 23: 210-215 (1987).

Ferguson, L. R.: Family interaction predictors of competence in late adolescence. Paper presented at the Biennial Meeting of the Soc. Res. Child Develop. Baltimore, MD. (1987).

McCleland, D.C.: The Achievement Motive.pp 33, Appleton/ Century/Crofts, New York (1953).

Misra, K.S.: Manual of Home Environment Inventory. Ankur Psychology Agency, Allahabad (1989).

Morrow, W.R. and Wilson, R.C.:Family relations of bright, high achieving and under achieving high school boys. Child Develop., 32: 501-510 (1961).

Paulson, S.E.: Maternal employment and adolescent achievement revisited: An ecological perspective. Fam. Rel., 45: 201-08 (1996)

Rotter Locus of Control http://www.ballarteduan/bsh/psych/rot. $\mathrm{Htm}$ (2002)

Scott, W. A. ,Scott, R. and McCabe, M.: Family relationships and children's personality: A cross-cultural, cross source comparison. Brit. J. Soc. Psychol., 30: 1-20 (1991). 